\title{
Üst ve alt solunum yolu enfeksiyonu olan hastalarda solunum virüslerinin multipleks PCR yöntemi ile eşzamanlı saptanması
}

\section{Simultaneous detection of respiratory viruses using multiplex PCR method in patients with upper and lower respiratory tract infection}

\author{
Candan ÇiçEK ${ }^{1}$ Ayşe ARSLAN ${ }^{1}$ Eylem Ulaş SAZ ${ }^{2}$ Hüsnü PULLUKÇU ${ }^{3}$ Gürsel ÇOK ${ }^{4}$ \\ ${ }^{1}$ Ege Üniversitesi Tıp Fakültesi, Tıbbi Mikrobiyoloji Anabilim Dalı, İzmir, Türkiye \\ ${ }^{2}$ Ege Üniversitesi Tıp Fakültesi, Çocuk Sağlığı ve Hastalıkları Anabilim Dalı, İzmir, Türkiye \\ ${ }^{3}$ Ege Üniversitesi Tıp Fakültesi, Enfeksiyon Hastalıkları Anabilim Dalı, İzmir, Türkiye \\ ${ }^{4}$ Ege Üniversitesi Tıp Fakültesi, Göğüs Hastalıkları Anabilim Dalı, İzmir, Türkiye
}

\section{Öz}

Amaç: Bu çalışmada, üst ve alt solunum yolu enfeksiyonu olan hastalarda multipleks PCR tanı yöntemi ile kısa sürede solunum virüslerinin saptanması amaçlandı.

Gereç ve Yöntem: Bu çalışmaya, Ocak 2007-Ağustos 2013 tarihleri arasında, üst veya alt solunum yolu enfeksiyonu ön tanısı alan, toplam 1708 (1220 çocuk, 488 erişkin) hasta (\%45.1 kadın, \%54.9 erkek, yaş aralığı 5 gün-94 yaş) dahil edildi. Hastaların solunum yolu örneklerindeki solunum virüsleri, mültipleks PCR yöntemi ile araştırıldı.

Bulgular: Toplam 1708 hastanın, 620'sinde (\%36.3) bir veya birden fazla solunum virüsü pozitif, 1088'inde (\%63.7) negatif bulundu. Bu hastaların 63'ünde (\%3.7) çoklu etken saptandı. Çoklu etken saptanan örneklerin \%89.5'i çocuk hastalardı. Solunum yolu örneklerinin 387'si (\%22.7) poliklinik hastalarından, 1321'i (\%77.3) yatan hastalardan elde edildi. Poliklinik hastalarının \%48.5'i, yatan hastaların \%32.7'sinde $(p<0.000)$, çocuk hastaların \%39.2'si, erişkin hastaların \%29.1'inde $(p<0.000)$ bir veya daha fazla solunum virüsü saptandı. Örneklerin tümünde influenza $\mathrm{A}(\mathrm{H} 1 \mathrm{~N} 1)$ pdm09 virüsü \%12.1, RSV \%9.0, rhinovirus \%3.7, influenza A virüsü \%3.0 oranında pozitif bulundu.

Sonuç: Akut solunum yolu enfeksiyonu olan hastaların yaklaşık \%40'ında solunum virüsleri pozitif bulundu. Hastaların yaklaşık \%4'ünde çoklu virüs enfeksiyonları saptandı ve bunların \%90'a yakınının çocuk hastalar olduğu görüldü. İnfluenza A(H1N1)pdm09 virüsü salgın nedeniyle ayrı tutulduğunda, en sık rastlanan üç patojenin sırasıyla; RSV, rhinovirus ve influenza A virüsü olduğu görüldü. Çocuklarda erişkin hastalara göre; poliklinik hastalarında, yatan hastalara göre daha fazla oranda solunum virüsü saptandı.

Anahtar Sözcükler: Multipleks PCR, solunum virüsleri.

\section{Abstract}

Aim: In this study, we aimed to determine the respiratory viruses in a short time by multiplex PCR method in patients with upper and lower respiratory tract infections.

Materials and Methods: In this report, between January 2007 and August 2013, a total of 1708 patients (1220 children, 488 adult; 45,1\% female, 54.9\% male, age range: 5 days-94 years) prediagnosed as having upper or lower respiratory tract infections were enrolled in the study. Respiratory viruses were investigated by multiplex PCR method in respiratory samples of these patients.

\footnotetext{
Yazışma Adresi: Candan ÇiçEK

Ege Üniversitesi Tıp Fakültesi, Tıbbi Mikrobiyoloji Anabilim Dalı, İzmir, Türkiye

Makalenin Geliş Tarihi: 27.01.2014 Kabul Tarihi: 10.02.2014
} 
Results: In a total of 1708 patients, 620 (36.3\%) of them were positive for one or more respiratory viruses and 1088 (63.7\%) were negative. In 63 of the patients (3.7\%) multiple viruses were detected. Most of the samples (89.5\%) containing multiple agents were detected in children. Respiratory specimens were obtained from 387 (22.7\%) outpatients and 1321 (77.3\%) inpatients. One or more respiratory viruses were detected in 39.2\% of pediatric patients, $29.1 \%$ of adult patients ( $p<0.000$ ), $48.5 \%$ of outpatients and $32.7 \%$ of inpatients. In all samples, influenza $A(H 1 N 1) p d m 09$ virus, $R S V$, rhinovirus and influenza $A$ virus were found be positive in $12.1 \%, 9.0 \%, 3.7 \%$ and $3.0 \%$, respectively.

Conclusion: Respiratory viruses were positive $40 \%$ in patients with acute respiratory tract infections. Multiple viral infections were detected in approximately $4 \%$ patients. Almost $90 \%$ of these patients were found to be of the pediatric patients. If influenza $A(H 1 N 1) p d m 09$ virus is kept separate, the three most common pathogen were RSV, rhinovirus and influenza $A$ virus, respectively. Respiratory viruses were detected more frequently in children compared to adult patients and in outpatient compared to hospitalized patients.

Keywords: Multiplex PCR, respiratory viruses.

\section{Giriş}

Viral etkenler nediyle oluşan solunum yolu enfeksiyonları; özellikle çocuk, yaşlı ve bağışık yetmezlikli hastalarda morbidite ve mortalitenin önde gelen nedenlerinden biridir. Solunum virüsleri ile oluşan enfeksiyonların çoğunun klinik belirti ve bulguları birbirine benzer ve bazıları belli yaşlarda ağır klinik tablo ile seyredebilir. Akut solunum yolu enfeksiyonu klinik tablosu ile başvuran hastaların önemli bir kısmında etkenin saptanması zordur. Günümüzde yetişkinlerde toplum kökenli pnömonilerin \%50'sinin, pediatrik yaş grubunda bronşiolit ve pnömonilerin \%15-35'inin etkeni hala saptanamamaktadır $(1,2)$. En sık solunum yolu enfeksiyonlarına neden olan influenza virüs tip $A$ ve $B$ (INF-A, INF-B), respiratory syncytial virüs (RSV), human rhinovirus (HRV), parainfluenza virus (PIV) ve adenovirus (ADV) gibi klasik solunum virüslerinin yanında, bu etkenlere son zamanlarda human coronovirus'ün (HCoV) yeni serotipleri, parvovirus, human metapneumovirus (HMPV) ve human bocavirus (HBoV) gibi yeni solunum virüsleri eklenmiştir (3-5). Viral etiyolojinin kısa sürede belirlenmesi gereksiz antibiyotik kullanımını önlemekte, antiviral tedavinin zamanında başlamasını sağlamakta ve enfeksiyonun yayılmasını engellemektedir. Solunum virüslerinin çoğunun çok fazla sayıda alt tipi bulunması, antijenik değişikliğe uğrayabilmeleri ve bazılarının kalıcı immünite bırakmaması nedeniyle tanıda direkt virüsü saptayan yöntemler kullanılmaktadır. Direkt yöntemlerde, hücre kültürü, direkt antijen testleri ve nükleik asit testleri en sık kullanılan yöntemlerdir (6). Solunum virüslerinin saptanmasında altın standart yöntem hücre kültürüdür. Ancak, yöntemin altın standart olma özelliğini koruyabilmesi için virüsün üreyebilmesi dolayısıyla canlı olması gerekmektedir. Bu yüzden soğuk zincir kurallarına uyulmadan gönderilen solunum örnekleri, test performansını olumsuz yönde etkilemektedir. Ayrıca bu yöntem, alt yapısı olan laboratuvarlarda uygulanabilmekte ve test prosedürü 3-14 gün sürebilmektedir (7). Son yıllarda, klinik örneklerde solunum yolu patojenlerinin hızlı tanısında kullanılan nükleik asit saptama teknikleri geliştirilmiştir. Multipleks PCR (mPCR) yönteminde, bir klinik örnek kullanılarak aynı reaksiyonda birden fazla solunum virüsü aynı anda saptanabilmektedir. Solunum virüslerinin; duyarlıığı yüksek, kısa sürede sonuçlanan ve tüm etkenlerin aynı anda belirlenebildiği mPCR tanı testi ile saptanması, hastaların erken dönemde daha iyi klinik bakım almalarını, morbite ve mortalite hızlarının da azalmasını sağlayabilir. Bu çalışmada, akut solunum yolu enfeksiyonu olan hastalarda solunum virüslerinin araştırılmasında, mPCR tanı yöntemi ile kısa sürede ve tek bir reaksiyonda etkenlerin saptanması amaçlanmıştır.

\section{Gereç ve Yöntem}

Bu çalışmada, Ocak 2007-Ağustos 2013 tarihleri arasında, üst veya alt solunum yolu enfeksiyonu ön tanısı alan, yaş aralığı 5 gün-94 yaş (medyan: 6 yaş) arasında değişen 1220 çocuk (medyan: 3 yaş), 488 erişkin (medyan: 46 yaş) toplam 1708 (\%45,1 kadın, $\% 54,9$ erkek) hastanın solunum yolu örnekleri toplandı. Nazofarengeal sürüntü (NFs) örnekleri viral taşıma besiyeri (UTM, Copan, İtalya) içinde, bronkoalveoler lavaj (BAL) ve transtrekeal aspirasyon (TTA) sıvıları steril kaplarda laboratuvara kabul edildi. Örneklerin tümüne $\mathrm{mPCR}$ tanı yöntemi uygulandı. Yaklaşık yedi yıllık sürede, ikisi de etkenleri bir veya iki reaksiyonda multipleks olarak çoğaltan, saptama yöntemleri birbirinden farklı iki ayrı mPCR kiti kullanıldı. Saptama yöntemlerine göre, 2007-2011 yılları arasında gelen 906 örnek ABI 7500 sisteminde real time PCR temelli "Respiratuvar RealAccurateTM (PathoFinder, Hollanda)" kiti, 2012-2013 yılları arasında gelen 802 örnek otomatize poliakilamid jel elektroforezi temelli "Screen Tape" çoklu tanımlama sistemi olan "RV15 ACE Detection (Seegene, Güney Kore)" kiti ile değerlendirildi. Ayrıca birinci dönemde kullanılan mPCR yöntemi ile influenza $A(H 1 N 1) p d m 09$ virüsü saptanamadığı için 2009-2010 yılları arasında tüm örneklere kantitatif real- 
time PCR (Invitrogen Corporation, ABD) testi de uygulandı.

Birinci dönemde klinik örneklerden nükleik asitlerin ekstraksiyonu RTP DNA/RNA Virus Mini Kit (Invitek $\mathrm{GmbH}$, Almanya) ile yapıldıktan sonra TaqMan primer ve probları [5' ucunda 6-karboksifloresan (FAM; florofor), 3' ucunda tetrametilrodamin (TAMRA; quencher) ile işaretli], enzim, dNTP, QiagenOne Step RT-PCR solüsyonu ve $\mathrm{dH} 2 \mathrm{O}$ karışımı örnek nükleik asidi ile yaklaşık 40 döngü yapıldı. $\mathrm{Bu}$ işlemle, cDNA'lar sentezlendi ve amplikonlar oluşturuldu. Amplikonların saptanmasında ABI 7500 (Applied Biosystems, ABD) sistemiyle floresans ışımalar ölçüldü. Testte, FAM floresans sinyali elde edilen örnek sonuçları pozitif olarak kabul edildi. Sinyalin döngülere göre açılımında, cycle treshold $(\mathrm{Ct})$ değeri 25-30 arasında olan örnekler güçlü pozitif, 30-35 arasında olanlar pozitif, 35-40 arasında olanlar düşük pozitif, 40 ve üzerinde olanlar negatif olarak kabul edildi. Örnekte, FAM floresans sinyali yokken sadece internal kontrolde floresans varsa, pozitif ve negatif kontroller doğru olarak sonuçlandıysa, test negatif olarak kabul edildi (internal kontrolün $\mathrm{Ct}$ değeri: 29-31). Örnekte, internal kontrolde ve/veya pozitif kontrollerde (pozitif kontrollerin Ct değeri 33-35 arasında) floresans yoksa test geçersiz kabul edildi ve tekrar edildi.

2009-2010 yılları arasında gelen klinik örneklerden H1N1 ekstraksiyonunda üretici firmanın önerileri doğrultusunda pürifikaskasyon materyali ile birlikte "iPrep PureLink Total RNA ve TRIzol Plus (Invitrogen Corporation, ABD)" kiti kullanıldı. Haziran 2009'da CDC'nin önerdiği primer ve probe setleri (Influenza $A$ H1N1 primer and probe set, SuperScript ${ }^{\mathrm{TM}}$ III Platinum ${ }^{\circledR}$ One-Step qRT-PCR kit Invitrogen Corporation, ABD) kullanılarak $A B I 7500$ sisteminde etken çoğaltıldı ve saptandı. Test protokolü "WHO Global Influenza Programı" sitesinde yer alan öneriler doğrultusunda uygulandı (8).

İkinci dönemde, nükleik asitlerin ekstrasiyonu, Viral DNA/RNA Extraction Kit (iNtRON, Güney Kore) ile yapıldı. Ekstraksiyon işleminden itibaren reaksiyona internal kontroller ilave edildi. Ektraksiyon işleminden sonra, revers transkripsiyon ile cDNA'lar sentezlendi (RevertAid First Strand cDNA Synthesis Kits, Fermentas, USA). İçeriğinde; solunum virüslerine özgül DPO primerleri, DNA polimeraz enzimi, dNTPs, mastermix, 8-MOP solüsyonu bulunan "RV15 ACE Screening (Seegene, Güney Kore)" kiti kullanılarak IS। döngü cihazında üretici firmanın önerileri doğrultusunda 40 döngü yapılarak cDNA'lar çoklu amplifiye edildi. Amplifiye ürün tam otomatize "Screen Tape" çoklu tanımlama cihazına yüklendi. Bu cihazda, PCR ürününe mini poliakrilamid jellerde otomatize jel elektroforezi yapıldı ve sonuçlar "RV15 ACE Screening Software" kullanılarak belirlendi.
Her iki testte de pozitif kontrol RNA'sı için kit içeriğinde bulunan hedef nükleik asitler ve standart pozitif kontroller, negatif kontrol olarak "RNase free" su kullanıldı. Her iki yöntemle; RSV, INF-A ve INF-B, PIV tip 1-4, ADV, HRV, HCoV, HMPV üretici firmanın önerileri doğrultusunda saptandı. İkinci dönem kullanılan "RV15 ACE Screening" kiti ile diğer solunum virüslerine ek olarak HBoV de saptandı.

İstatistik analizlerde Pearson chi-square ve SPSS (v. 21) kullanıldı. $p<0.05$ anlamlı kabul edildi.

\section{Bulgular}

Toplam 1708 hastanın, 620'sinde (\%36.3) solunum virüsleri pozitif, 1088'inde (\%63.7) ise negatif bulundu. Klinik örneklerin \%94.4'ü NFs, \%4.1'i BAL ve \%1.5'i TTA'ydı. Hastaların 57'sinde (\%3.3) iki etken, 6'sında $(\% 0.4)$ üç etken saptandı. Çoklu etken bulunan örneklerin \%89.5'i çocuklarda, \%10.5'i erişkin hastalarda saptandı. Örneklerin tümünde, $\mathrm{H} 1 \mathrm{~N} 1 \% 12.1$, RSV \%11,0, HRV \%5,6 ve INF-A \%4.2 oranında bulundu (Tablo-1).

Solunum yolu örneklerinin 383'ü (\%22.4) poliklinik, 1325 'i (\%77.6) servislerde yatan hastalardan elde edildi. Poliklinik hastalarının \%47.5'i, yatan hastaların \%33.0'ında $(p<0.000)$, çocuk hastaların \%39.2'si, erişkin hastaların \%29.1'inde $(p<0.000)$ bir veya birden fazla solunum virüsü pozitif bulundu. Solunum virüsleri pozitif olan poliklinik hastalarının $(n=182), \% 79.1$ 'inde $H 1 N 1$, \%13.2'sinde HRV, \%3.8'inde INF-A saptandı. Hiç bir poliklinik hastasında INF-B, HCoV, HMPV, HBoV, PIV tip 1-4 izole edilmedi. Solunum virüsleri pozitif bulunan yatan hastaların $(n=438), \% 34.5$ 'inde RSV, \%14.1'inde H1N1, \%10.3'ünde INF-A, \%7.3'ünde PIV (\%68.7'si PIV3) ve \%6.2'sinde ADV saptandı. Çoklu etken enfeksiyonlarının \%96.8'i yatan hastalardan soyutlandı (Şekil-1). Örneklerin ve etkenlerin aylara göre dağılımı Tablo-2'de gösterildi.

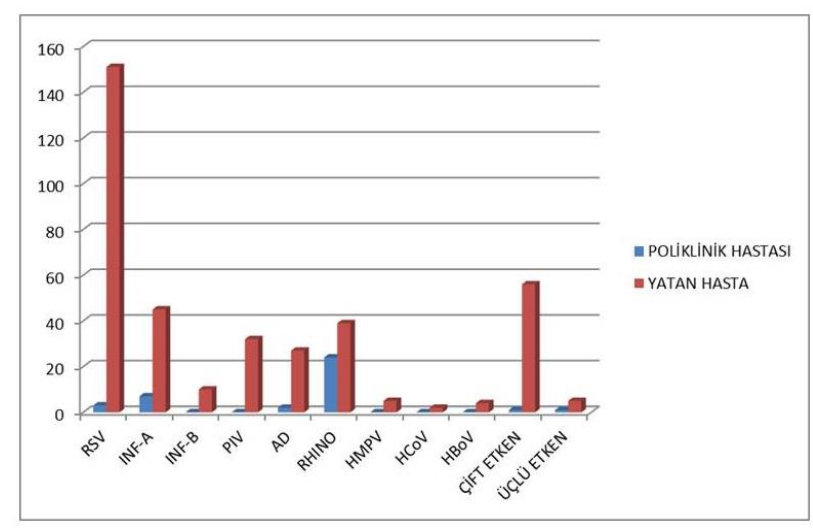

Şekil-1. Poliklinik hastaları ve yatan hastalarda solunum virüslerinin dağılımı. (INF-A: İnfluenza A virüs, INF-B: İfluenza $B$ virüs, PIV: Parainfluenza virüs, AD: Adenovirus, RHINO: Human rhinovirus, HMPV: Human metapneumovirus, HCoV: Human coronavirus, HBoV: Human bocavirus) 
Tablo-1. Üst ve Alt Solunum Yolu Enfeksiyonu Olan Hastalarda Solunum Virüslerinin Dağıımı.

\begin{tabular}{|c|c|c|c|c|}
\hline Grup & Virüsler & $\begin{array}{l}\text { Çocuk } \\
\text { n (\%) }\end{array}$ & $\begin{array}{c}\text { Yetişkin } \\
\mathbf{n}(\%)^{*}\end{array}$ & $\begin{array}{l}\text { Toplam } \\
\text { n (\%) }\end{array}$ \\
\hline \multirow{13}{*}{$\begin{array}{l}\text { Tek virüs } \\
\text { enfeksiyonu }\end{array}$} & RSV & $141(11.6)$ & $13(2.7)$ & $154(9.0)$ \\
\hline & HRV & $52(4.3)$ & $11(2.3)$ & $63(3.7)$ \\
\hline & INF-A & $43(3.5)$ & $9(1.8)$ & $52(3.0)$ \\
\hline & $\mathrm{H} 1 \mathrm{~N} 1$ & $117(9.6)$ & $89(18.2)$ & $206(12.1)$ \\
\hline & INF-B & $9(0.7)$ & $1(0.2)$ & $10(0.6)$ \\
\hline & HMPV & $5(0.4)$ & 0 & $5(0.3)$ \\
\hline & $\mathrm{HBoV}$ & $3(0.2)$ & $1(0.2)$ & $4(0.2)$ \\
\hline & $\mathrm{HCoV}$ (OC43/229E/NL63) & $2(0.2)$ & 0 & $2(0.1)$ \\
\hline & PIV-1 & $5(0.4)$ & $2(0.4)$ & $7(0.4)$ \\
\hline & PIV-2 & $1(0.1)$ & 0 & $1(0.1)$ \\
\hline & PIV-3 & $19(1.6)$ & $3(0.6)$ & $22(1.3)$ \\
\hline & PIV-4 & $1(0.1)$ & $1(0.2)$ & $2(0.1)$ \\
\hline & ADV & $23(1.9)$ & $6(1.2)$ & $29(1.7)$ \\
\hline \multirow{22}{*}{$\begin{array}{l}\text { İkili etken } \\
\text { enfeksiyonları }\end{array}$} & $\mathrm{RSV}+\mathrm{HRV}$ & $12(1)$ & $1(0.2)$ & $13(0.8)$ \\
\hline & $\mathrm{RSV}+\mathrm{ADV}$ & $3(0.3)$ & 0 & $3(0.2)$ \\
\hline & $\mathrm{RSV}+\mathrm{PIV}-1$ & $1(0.1)$ & 0 & $1(0.1)$ \\
\hline & RSV + PIV-3 & $4(0.4)$ & $1(0.2)$ & $5(0.4)$ \\
\hline & RSV + INF-B & $1(0.1)$ & 0 & $1(0.1)$ \\
\hline & RSV + INF-A & $7(0.6)$ & $2(0.4)$ & $9(0.6)$ \\
\hline & $\mathrm{RSV}+\mathrm{HBoV}$ & $2(0.2)$ & 0 & $2(0.2)$ \\
\hline & $\mathrm{HRV}+\mathrm{HCoV}$ & $4(0.4)$ & 0 & $4(0.3)$ \\
\hline & HRV + INF-A & $3(0.3)$ & 0 & $3(0.2)$ \\
\hline & HRV + HMPV & $1(0.1)$ & 0 & $1(0.1)$ \\
\hline & $\mathrm{HRV}+\mathrm{PIV}-1$ & $1(0.1)$ & 0 & $1(0.1)$ \\
\hline & $\mathrm{HRV}+\mathrm{PIV}-2$ & $1(0.1)$ & 0 & $1(0.1)$ \\
\hline & $\mathrm{HRV}+\mathrm{PIV}-3$ & $1(0.1)$ & $1(0.2)$ & $2(0.2)$ \\
\hline & HRV + PIV-4 & $1(0.1)$ & 0 & $1(0.1)$ \\
\hline & $\mathrm{HRV}+\mathrm{ADV}$ & $3(0.3)$ & 0 & $3(0.2)$ \\
\hline & HRV + Enterovirus & $1(0.1)$ & 0 & $1(0.1)$ \\
\hline & INF-A + Enterovirus & 0 & $1(0.2)$ & $1(0.1)$ \\
\hline & INF-A + PIV-3 & $1(0.1)$ & 0 & $1(0.1)$ \\
\hline & INF-A + ADV & $1(0.1)$ & 0 & $1(0.1)$ \\
\hline & $\mathrm{INF}-\mathrm{A}+\mathrm{HCoV}$ & $1(0.1)$ & 0 & $1(0.1)$ \\
\hline & $\mathrm{H} 1 \mathrm{~N} 1$ + ADV & $1(0.1)$ & 0 & $1(0.1)$ \\
\hline & $A D V+P I V-3$ & $1(0.1)$ & 0 & $1(0.1)$ \\
\hline \multirow{6}{*}{$\begin{array}{l}\text { Üçlü etken } \\
\text { enfeksiyonları }\end{array}$} & INF-A + RSV + HBoV & $1(0.1)$ & 0 & $1(0.1)$ \\
\hline & INF-A + RSV + PIV-1 & $1(0.1)$ & 0 & $1(0.1)$ \\
\hline & INF-A + RSV + ADV & $1(0.1)$ & 0 & $1(0.1)$ \\
\hline & $\mathrm{RSV}+\mathrm{HRV}+\mathrm{HMPV}$ & $1(0.1)$ & 0 & $1(0.1)$ \\
\hline & $\mathrm{RSV}+\mathrm{HRV}+\mathrm{HCoV}$ & $1(0.1)$ & 0 & $1(0.1)$ \\
\hline & $\mathrm{RSV}+\mathrm{HRV}+\mathrm{ADV}$ & $1(0.1)$ & 0 & $1(0.1)$ \\
\hline \multicolumn{2}{|l|}{ Pozitif } & $478(39.2)$ & $142(29.1)$ & $620(36.3)$ \\
\hline \multicolumn{2}{|l|}{ Negatif } & $742(60.8)$ & $346(70.9)$ & $1088(63.7)$ \\
\hline \multicolumn{2}{|l|}{ Toplam } & 1220 & 488 & 1708 \\
\hline
\end{tabular}

*Sütun yüzdesidir. (HRV: Human rhinovirus, INF-A: İnfluenza A virüs, INF-B: İfluenza B virüs, H1N1: Pandemik influenza A H1N1 virüsü, HMPV: Human metapneumovirus, HBoV: Human bocavirus, HCoV: Human coronavirus, PIV1: Parainfluenza virüs tip 1, PIV2: Parainfluenza virüs tip 2, PIV3: Parainfluenza virüs tip 3, PIV4: Parainfluenza virüs tip 4, ADV: Adenovirus) 
Tablo-2. Solunum Virüslerinin Aylara Göre Dağılımı.

\begin{tabular}{|c|c|c|c|c|c|c|c|c|c|c|c|c|c|}
\hline Etken & ర్ల్ల & $\begin{array}{l}\frac{\pi}{\pi} \\
\frac{0}{5} \\
\infty\end{array}$ & $\sum_{\Sigma}^{\frac{t}{\pi}}$ & $\begin{array}{l}\text { 탞 } \\
\frac{\mathscr{S}}{Z}\end{array}$ & $\sum_{\sum}^{\infty}$ & 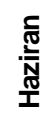 & $\underset{\stackrel{N}{\mathcal{E}}}{\stackrel{N}{\varrho}}$ & $\begin{array}{l}\text { 足 } \\
\text { 总 } \\
\text { 要 }\end{array}$ & 衣 & $\frac{E}{\frac{E}{4}}$ & 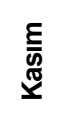 & $\begin{array}{l}\text { 兰 } \\
\frac{\sqrt{0}}{\alpha}\end{array}$ & Toplam \\
\hline RSV & 54 & 26 & 22 & 10 & 2 & 9 & 10 & 3 & 1 & 3 & 3 & 11 & 154 \\
\hline INF-A & 13 & 11 & 7 & 1 & 0 & 1 & 1 & 0 & 7 & 0 & 6 & 5 & 52 \\
\hline INF-B & 5 & 1 & 1 & 1 & 0 & 0 & 0 & 0 & 1 & 0 & 1 & 0 & 10 \\
\hline H1N1 & 1 & 0 & 0 & 0 & 0 & 0 & 0 & 0 & 0 & 0 & 135 & 70 & 206 \\
\hline PIV1 & 3 & 0 & 0 & 0 & 0 & 1 & 2 & 0 & 1 & 0 & 0 & 0 & 7 \\
\hline PIV2 & 0 & 0 & 0 & 0 & 0 & 0 & 0 & 0 & 0 & 0 & 0 & 1 & 1 \\
\hline PIV3 & 3 & 2 & 3 & 2 & 1 & 2 & 1 & 3 & 2 & 2 & 1 & 0 & 22 \\
\hline PIV4 & 0 & 0 & 0 & 1 & 0 & 0 & 0 & 0 & 0 & 0 & 1 & 0 & 2 \\
\hline HMPV & 1 & 0 & 0 & 2 & 0 & 0 & 0 & 0 & 0 & 0 & 0 & 2 & 5 \\
\hline HCoV & 0 & 0 & 0 & 0 & 2 & 0 & 0 & 0 & 0 & 0 & 0 & 0 & 2 \\
\hline HRV & 6 & 1 & 2 & 12 & 7 & 12 & 5 & 1 & 6 & 2 & 6 & 3 & 63 \\
\hline HBoV & 1 & 0 & 0 & 0 & 0 & 1 & 1 & 0 & 0 & 0 & 0 & 1 & 4 \\
\hline ADV & 3 & 5 & 5 & 3 & 2 & 0 & 0 & 0 & 1 & 3 & 4 & 3 & 29 \\
\hline İkili etken & 11 & 7 & 4 & 7 & 5 & 1 & 5 & 1 & 4 & 1 & 4 & 7 & 57 \\
\hline $\begin{array}{l}\text { Üçlü } \\
\text { etken }\end{array}$ & 0 & 1 & 1 & 1 & 0 & 1 & 0 & 0 & 0 & 0 & 1 & 1 & 6 \\
\hline Negatif & 159 & 104 & 80 & 67 & 62 & 70 & 52 & 35 & 63 & 41 & 64 & 291 & 1088 \\
\hline
\end{tabular}

(INF-A: İnfluenza A virüs, INF-B: İnfluenza B virüs, H1N1: Pandemik influenza H1N1, PIV1: Parainfluenza virüs tip 1, PIV2: Parainfluenza virüs tip 2, PIV3: Parainfluenza virüs tip 3, PIV4: Parainfluenza virüs tip 4, HMPV: Human metapneumovirus, HCoV: Human coronavirus, HRV: Human rhinovirus, HBoV: Human bocavirus, ADV: Adenovirus)

\section{Tartışma}

Virüsler akut solunum yolu enfeksiyonlarına neden olan etkenlerin başında gelmektedir. Parainfluenza virüsleri, INF-A, INF-B, ADV ve RSV gibi daha önceden etken olduğu bilinen solunum virüslerine 2000 yılından sonra HMPV, HBoV, HCoV'nin NL63, HKU1 ve SARS-CoV serotipleri olmak üzere beş yeni virüs daha eklenmiştir. Ayrıca INF-A'nin yeni serotipleri olan kuş kökenli H5N1 ve domuz kökenli H1N1 ile salgınlar yaşanmıştır (9-11). Viral solunum yolu enfeksiyonlarının tanısında viroloji laboratuvarlarında kullanılan direkt flöresan antikor (DFA) testi ve hücre kültürü gibi geleneksel yöntemler ile altı veya yedi solunum virüsü saptanabilmektedir (12). Yeni solunum virüslerinin keşfi ile viroloji laboratuvarlarında solunum virüslerinin tanısında geleneksel yöntemlerin dışında, bu virüsleri de saptayabilecek yeni yöntemleri içeren değişiklikler yapma zorunluluğu doğmuştur. Son yıllarda solunum virüslerinin saptanmasında çok sayıda nükleik asit amplifikasyon testleri geliştirilmiştir. Yapılan çalışmalarda bu testlerin duyarlılık ve özgüllükleri geleneksel yöntemlerden daha üstün bulunmuştur. Multipleks PCR yöntemi ile bir veya birden fazla solunum virüsünü eş zamanlı saptamak olasıdır (13-16). Bu çalışmada, yaklaşık yedi yıllık sürede Ege Üniversitesi Tıp Fakültesi Hastanesi'ne akut solunum yolu enfeksiyonu ile başvuran hastaların klinik örneklerinde solunum virüslerinin saptanması amacıyla, son yıllarda geliştirilen ve etkenleri kısa sürede tek bir reaksiyonda saptayabilen $\mathrm{mPCR}$ testi uygulanmıştır.

Bu çalışmada, akut üst veya alt solunum yolu şikâyeti ile hastaneye başvuran, ayaktan veya yatarak izlenen hastaların yaklaşık \%40'ında solunum virüsleri pozitif bulunmuştur. Hastaların yaklaşık \%4'ünde çoklu etken enfeksiyonları saptanmış ve bunların \%90'a yakının çocuk hastalar olduğu görülmüştür. Solunum yolu örnekleri en fazla Aralık, Ocak ve Şubat aylarında gelmiş ve en sık NFs klinik örnek olarak kabul edilmiştir. Salgına neden olan H1N1 mevsimsel seyreden virüslerden ayrı incelendiğinde, en sık rastlanan üç patojenin sırasıyla; RSV (\%11.0), HRV (\%5.6) ve INF-A (\%4.2) olduğu görülmüştür. Çocuklarda erişkin hastalara göre viral solunum yolu patojenleri ile enfekte olma oranı istatistiksel olarak anlamlı derece yüksek bulunmuştur. Çocuklarda en sık etken olarak RSV izole edilmiş ve bunu HRV, INF-A ve PIV takip etmiştir. Erişkinlerde ise salgın döneminde en sık saptanan patojen $\mathrm{H} 1 \mathrm{~N} 1$ virüsü olmuştur. Bunun dışında, normal mevsimsel dönemlerde ise erişkin hastalarda, RSV, HRV ve INF-A virüslerinin oranları birbirine yakın bulunmuştur. Birden fazla patojen saptanan hastalarda, en sık RSV ve HRV ikili etken 
enfeksiyonu görülmüştür. Poliklinik hastalarında yatan hastalara göre solunum virüslerinin pozitif bulunma oranı istatistiksel olarak anlamlı derecede yüksek bulunmuştur. Poliklinik hastalarında H1N1 salgını dışında en sık HRV (\%13.2) ve INF-A (\%3.8) saptanmıştır. Yatan hastalarda ise etken olarak en sık RSV (\%34.5) saptanmış, bunu INF-A (\%10.3) ve çoğunluğu PIV3 olmak üzere PIV (\%7.3) izlemiştir. RSV'nin en sık, Aralık ve Mart ayları arasında, influenza virüslerinin OcakŞubat aylarında, HRV'nin ise en sık Nisan-Haziran ayları arasında etken olduğu görülmüştür. Çoklu etken enfeksiyonlarının ise en sık Ocak aylarında görüldüğü saptanmıştır. Diğer virüslerle olan solunum yolu enfeksiyonları yıl boyunca sporadik seyretmiştir. Yapılan diğer çalışmalarla karşılaştırıldığında; ülkemizdeki çalışmalarda solunum virüslerinin pozitiflik oranları \%34.4-\%67.8 arasında bulunmuştur $(17,18)$. Yurt dışı çalışmalarında ise Amerika'da \%36.5, Güney Doğu Asya'da \%32, Avrupa'da yaklaşık \%43 oranında solunum virüsleri akut solunum yolu enfeksiyonu olan hastalarda pozitif bulunmuştur (19-22). Bu çalışmada elde edilen pozitiflik oranı daha önce yapılan çalışmaların çoğu ile benzerlik göstermektedir.

Akut solunum yolu enfeksiyonu olan hastalarda, çoklu enfeksiyon oranları farklı çalışmalarda \%3.0 ile \%7.8 arasında bulunmuştur (17,19,21-24). Bu çalışmada, klinik örneklerin \%3.7'sinde iki veya üç etken saptanmıştır. Solunum virüsleri ile gelişen solunum yolu enfeksiyonları mevsimsel özellik göstermektedir. Daha önce yapılan çalışmalarda solunum virüslerinin özellikle kış aylarında ve Kasım-Mart ayları arasında etkin oldukları bildirilmiştir $(21,24,25)$. Bu çalışmada da, bölgemizde solunum virüslerinin en çok kış aylarında ve ilkbahar girişinde enfeksiyonlarda etken olarak saptandığı görülmüştür.

Son yıllarda etken olan çok sayıda solunum virüsünün çoğunu aynı anda saptayabilen mültipleks bazlı nükleik asit testleri geliştirilmiştir. Multipleks PCR yöntemi ile solunum virüslerinin kısa sürede tanımlanması; klinik kararların erken alınmasını sağlayarak hasta yönetimini daha etkin hale getirmekte ve antibiyotik kullanımını azaltmaktadır. Bunun yanında bu yöntemler, hücre kültürü ve DFA ile saptanamayan diğer solunum virüslerini de saptayabilmektedir. Ayrıca, bu tanı yöntemi ile hem duyarlı hem de hızlı sonuç alınmasıyla solunum virüslerinin mevsimsel salgınları daha erken dönemde fark edilebilmektedir. Bu çalışmada yıllara göre iki farklı mPCR yöntemi kullanılmıştır. Birinci dönemde kullanılan mPCR yöntemi ile H1N1 saptanamadığı için 2009 yılında salgın başlangıcı ile birlikte, solunum virüsleri tanı yöntemine sadece $\mathrm{H} 1 \mathrm{~N} 1$ 'in saptandığı başka bir real time yöntemi eklenmiştir. Daha sonra H1N1'in mevsimsel özellik kazanmasıyla, laboratuvarımızda influenza $A$ virüsünün bu kökenini de saptayabilen yeni bir mPCR yöntemi kullanılmaya başlanmıştır. Ayrıca, ikinci dönem kullanılan mPCR ile HBoV de saptanabilmektedir. Bu yüzden bu çalışmadaki HBoV sonuçları sadece 2012-2013 yıllarına aittir. Daha önce, "Respiratuvar RealAccurateTM" (PathoFinder, Hollanda) ile yapılmış bir çalışmada duyarlılık ve özgüllük hücre kültürü ile karşılaştırıldığında sırasıyla; $\% 94.0$ ve $\% 100$, PPV \%57.8, NPV \%43.0 olarak bulunmuştur (26). "RV15 ACE Detection" kiti (Seegene, Güney Kore) ile daha önce yapılan üç çalışmada, kitin duyarlılık ve özgüllüğü hücre kültürü ile karşılaştırılmış ve duyarlılık-özgüllük oranları sırasıyla \%100-\%87.0, \%88.6-\%100 ve \%98.0$\% 100$ olarak bulunmuştur $(16,27,28)$. Bu çalışmada kullanılan her iki mPCR yönteminin solunum virüslerini saptamada duyarlılık ve özgüllüklerinin yüksek olduğu diğer çalışmalarda gösterilmiştir.

\section{Sonuç}

Akut solunum yolu enfeksiyonu olan hastaların yaklaşık \%40'ında solunum virüsleri saptanmıştır. Poliklinik hastalarında HRV'nin, yatan hastalarda RSV'nin diğer solunum virüslerine kıyasla daha fazla oranda etken olduğu belirlenmiştir. İnfluenza A virüsü hem poliklinik hem de yatan hastalarda ikinci sırada olmakla birlikte yatan hastalarda daha fazla oranda etken olarak saptanmıştır. Bölgemizde solunum virüslerinin en sık kış aylarında ve ilkbahar mevsimi girişinde etken olduğu görülmüştür. Kullanılan mPCR yöntemlerinin duyarlı ve özgül olduğu, kısa sürede sonuçlandığı için hasta yönetimine fayda sağladığı sonucuna varılmıştır. Ayrıca, hücre kültürü ve DFA ile saptanamayan veya saptanması zor olan HCoV, HBoV, HRV, HMPV gibi virüsleri de belirleyerek viral etiyolojiye katkıda bulunmuştur.

\section{Kaynaklar}

1. Davies HD, Matlow A, Petric M, Glazier R, Wang EE. Prospective comparative study of viral, bacterial and atypical organisms identified in pneumonia and bronchiolitis in hospitalized Canadian infants. Pediatr Infect Dis J 1996;15(4):371-5.

2. Hamelin ME, Abed Y, Boivin G. Human metapneumovirus: A new player among respiratory viruses. Clin Infect Dis 2004;38(7):983-90.

3. Barenfanger J, Drake C, Leon N, Mueller T, Troutt T. Clinical and financial benefits of rapid detection of respiratory viruses: An outcomes study. J Clin Microbiol 2000;38(8):2824-8.

4. Van den Hoogen BG, Osterhaus DM, Fouchier RA. Clinical impact and diagnosis of human metapneumovirus infection. Pediatr Infect Dis J 2004;23(1 Suppl):S25-S32. 
5. Ksiazek TG, Erdman D, Goldsmith CS, et al. A novel coronavirus associated with severe acute respiratory syndrome. $\mathrm{N}$ Engl $\mathrm{J}$ Med 2003;348(20):1953-66.

6. Loeffelholz M, Chonmaitree T. Advances in diagnosis of respiratory virus infections. Int J Microbiol 2010;2010:126049.

7. Çiçek C. Hücre kültürü teknikleri: Tek tabaka hücre kültürlerinin üretilmesi ve idame ettirilmesi. In: Başustaoğlu A, Yıldırım ŞT (eds). Klinik Mikrobiyoloji Yöntemleri El Kitabı. 3. Cilt, 3. Baskı. Ankara; Atlas Kitapçılık: 2014.

8. Centers for Disease Control and Prevention (CDC) protocol of real time RT-PCR for influenza A(H1N1) October 2009 publications/swineflu/CDCrealtime RTPCR protocol_20.090.428.pdf. Available from: www.cdc.gov/h1n1flu/guidance

9. Drosten C, Gunther S, Preiser W, van der Werf S, Brodt JR, Becker S. Identification of a novel coronavirus in patients with severe acute respiratory syndrome. N Engl J Med 2003;348(20):1967-78.

10. Falsey AR, Walsh EE, Hayden FG. Rhinovirus and coronavirus infection associated hospitalisations among older adults. $\mathrm{J}$ Infect Dis 2002;185(9):1338-41.

11. Zambon MC, Stockton J, Clewley J, Fleming DF. Contribution of influenza and respiratory syncytial virus to community cases of influenza- like illness: an observational study. Lancet 2001;358(9291):1410-6.

12. Mahony JB, Blackhouse G, Babwah J, et al. Cost analysis of multiplex PCR testing for diagnosing respiratory virus infections. J Clin Microbiol 2009;47(9):2812-7.

13. Bellau-Pujol S, Vabret A, Legrand L, et al. Development of three multiplex RT-PCR assays for the detection of 12 respiratory RNA viruses. J Virol Methods 2005;126(1-2):53-63.

14. Coiras M T, Aguilar JC, Garcia ML, Casas I, Perez-Brena P. Simultaneous detection of fourteen respiratory viruses in clinical specimens by two multiplex reverse transcription nested-PCR assays. J Med Virol 2004;72(3):484-95.

15. Coiras MT, Lopez-Huertas MR, Lopez-Campos G, Aguilar JC, Perez-Brena P. Oligonucleotide array for simultaneous detection of respiratory viruses using a reverse-line blot hybridization assay. J Med Virol 2005;76(2):256-64.

16. Coiras MT, Perez-Brena P, Garcia ML, Casas I. Simultaneous detection of influenza A, B and C viruses, respiratory syncytia virus, and adenoviruses in clinical samples by multiplex reverse transcription nested-PCR assay. J Med Virol 2003;69(1):13244.

17. Ecemiş T, Yılmaz Ö, Şanlıdağ T, Akçalı S, Yüksel H. Üst solunum yolu infeksiyonlu çocuklarda viral etkenlerin multipleks PCR ile araştırılması. Dr. Behçet Uz Çocuk Hastanesi Dergisi 2012;2(1):1-5.

18. Sancaklı Ö, Yenigün A, Kırdar S. Alt solunum yolu enfeksiyonunda nazofaringeal örneklerde polimeraz zincir reaksiyonu sonuçları. J Pediatr Inf 2012;6(3):84-9.

19. Brittain-Long R, Westinb J, Olofssonb S, Lindhb M, Anderssona L. Prospective evaluation of a novel multiplex real-time PCR assay for detection of fifteen respiratory pathogens--duration of symptoms significantly affects detection rate. $\mathrm{J}$ Clin Virology 2010;47(3):263-7.

20. Obasi C, Barrett B, Brown R, Vrtis R, Barlow S, Muller D, Gern J. Detection of viral and bacterial pathogens in acute respiratory infections. J Infect 2014;68(2):125-30.

21. Tsai HP, Kuo PH, Liu CC, Wang JR. Respiratory viral infections among pediatric inpatients and outpatients in Taiwan from 1997 to 1999. J Clin Microbiol 2001;39(1):111-8.

22. Pierangeli $A$, Gentile M, Di Marco P, et al. Detection and typing by molecular techniques of respiratory viruses in chidren hospitalized for acute respiratory infection in Rome, Italy. J Med Virol 2007;79(4):463-8.

23. Renois F, Talmud D, Huguenin A, et al. Rapid detection of respiratory tract viral infections and coinfections in patients with influenza-like illnesses by use of reverse transcription-PCR DNA microarray systems. J Clin Microbiol 2010;48(11):3836-42.

24. Jin YS, Kuak EY, Shin BM. Detection of 12 respiratory viruses with two-set multiplex reverse transcriptase-PCR assay using a dual priming oligonucleotide system. Korean J Lab Med 2007;27(6):420-7.

25. Eccles R. An Explanation for the seasonality of acute upper respiratory tract viral infections. Acta Otolaryngol 2002;122(2):18391.

26. Reijans $\mathrm{M}$, Dingemans $\mathrm{G}$, Klaassen $\mathrm{CH}$, et al. RespiFinder: A new multiparameter test to differentially identify fifteen respiratory viruses. J Clin Microbiol 2008;46(4):1232-40.

27. Syrmis MW, Whiley DM, Thomas M, et al. A sensitive, specific, and cost-effective multiplex reverse transcriptase-PCR assay for the detection of seven common respiratory viruses in respiratory samples. J Mol Diagnostic 2004;6(2):125-31.

28. Bellau-Pujol S, Vabret A, Legrand L, et al. Development of three multiplex RT-PCR assays for the detection of 12 respiratory RNA viruses. J Virol Method 2005;126(1):53-63. 